
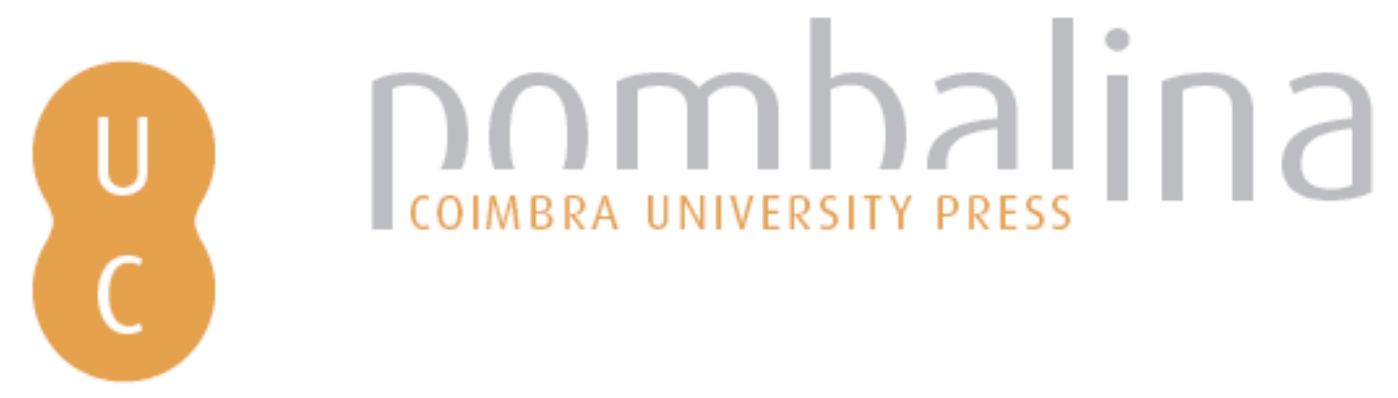

\title{
Multidisciplinary fire science research at the Sycan Marsh, Oregon
}
Autor(es):
Parsons, Russ; Sauerbrey, Katie; Vaillant, Nicole; Queen, Lloyd; Moran, Chris; Cunningham, Matt; Grulke, Nancy; Bienz, Craig; Butler, Bret

Publicado por: Imprensa da Universidade de Coimbra

URL

persistente:

URI:http://hdl.handle.net/10316.2/44665

DOI:

DOI:https://doi.org/10.14195/978-989-26-16-506_148

Accessed : $\quad$ 26-Apr-2023 15:09:17

A navegação consulta e descarregamento dos títulos inseridos nas Bibliotecas Digitais UC Digitalis, UC Pombalina e UC Impactum, pressupõem a aceitação plena e sem reservas dos Termos e Condições de Uso destas Bibliotecas Digitais, disponíveis em https://digitalis.uc.pt/pt-pt/termos.

Conforme exposto nos referidos Termos e Condições de Uso, o descarregamento de títulos de acesso restrito requer uma licença válida de autorização devendo o utilizador aceder ao(s) documento(s) a partir de um endereço de IP da instituição detentora da supramencionada licença.

Ao utilizador é apenas permitido o descarregamento para uso pessoal, pelo que o emprego do(s) título(s) descarregado(s) para outro fim, designadamente comercial, carece de autorização do respetivo autor ou editor da obra.

Na medida em que todas as obras da UC Digitalis se encontram protegidas pelo Código do Direito de Autor e Direitos Conexos e demais legislação aplicável, toda a cópia, parcial ou total, deste documento, nos casos em que é legalmente admitida, deverá conter ou fazer-se acompanhar por este aviso.

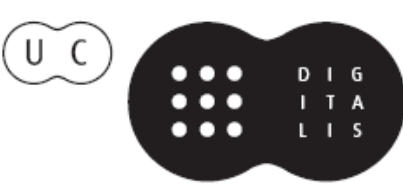




\section{ADVANCES IN}

\section{FOREST FIRE RESEARCH}

\section{8}

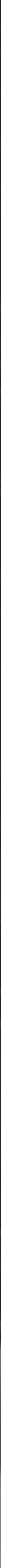


Short contribution - Fuel Management

\title{
Multidisciplinary fire science research at the Sycan Marsh, Oregon
}

\author{
Russ Parsons ${ }^{1}$; Katie Sauerbrey ${ }^{2}$; Nicole Vaillant ${ }^{3}$; Lloyd Queen ${ }^{4}$; Chris Moran ${ }^{4}$; Matt Cunningham ${ }^{4}$; \\ Nancy Grulke ${ }^{5}$; Craig Bienz ${ }^{6}$; Bret Butler ${ }^{1}$ \\ ${ }^{I}$ USFS RMRS, Fire Sciences Lab. 5775 Highway 10 W, Missoula, MT, \{rparsons@fs.fed.us*, \\ bwbutler@fs.fed.us\} \\ ${ }^{2}$ Nature Conservancy, Klamath Basin Field Office \{katie.sauerbrey@tnc.org\} \\ ${ }^{3}$ USFS PNWRS, Wildland Fire Management RD\&A, \{nvaillant@fs.fed.us\} \\ ${ }^{4}$ University of Montana, National Center for Landscape Fire Analysis, \{lloyd.queen@firecenter.umt.edu, \\ chris.moran@firecenter.umt.edu, matt.cunningham@firecenter.umt.edu\} \\ ${ }^{5}$ USFS PNWRS WWETAC, Prineville, OR \{ngrulke@fs.fed.us\} \\ ${ }^{6}$ Nature Conservancy, Klamath Basin Field Office \{cbienz@tnc.org\}
}

\begin{abstract}
In October 2017, a diverse campaign of fire research was carried out in the context of management prescribed burns at the Nature Conservancy's Sycan Marsh Preserve, a relatively isolated site in south central Oregon characterized by extensive grasslands, dry ponderosa pine forests and unique wetland habitats. The overarching objective of this effort was to develop integrated and reliable fuels, weather and fire behavior datasets for evaluation of different fire models. This broad goal required an integrated methods approach to facilitate fuel mapping and fire behavior observation and measurements at multiple scales. Fuel mapping efforts, intended to provide 3D inputs for physics-based fire models, link traditional surface fuels and tree measurement sampling with new approaches that enable development of comprehensive data across larger areas. These new approaches include a mobile app-based tool for surface fuels, drone imagery-based mapping, airborne LiDAR data, and 3D modeling using the STANDFIRE prototype fuel modeling platform. Wind measurements included a large network of $3 \mathrm{~m}$ anemometer towers and a SODAR instrument to capture the vertical wind profile in 3D. Emissions data collection included vehicle and aerostat mounted sensors sampling particulates and gas concentrations. Fire behavior measurements included surface instruments and thermal imagery from fixed wing and drone platforms. This presentation will provide an overview of the overall experiment, present some preliminary data, and discuss future directions. With more research burns planned in the months and years to come, we see the Sycan Marsh Preserve as a site for collaborative fire science research, and as a test bed for new methods and approaches in mapping fuels in 3D at landscape scales, integration of fire behavior and weather data across scales, and in data and approaches for evaluating models across scales and different levels of detail.
\end{abstract}

Keywords: Fuel Mapping, Fuel modeling, Prescribed Fire, Fire Behavior, UAS, Drones, Thermal Imagery

\section{Site Description}

The Sycan Marsh Preserve is a 12,364 ha preserve in south central Oregon owned and managed by The Nature Conservancy, a non-profit dedicated to natural resource conservation. In many of its preserves, The Nature Conservancy considers active management, such as forest fuel treatments and prescribed fires, as key components in their stewardship and restoration strategies. Located on mostly flat terrain at an elevation of around 1585m, the Sycan Marsh Preserve is predominantly grass and wetlands but has extensive forest areas, dominated by ponderosa pine, at the margins of the marsh. Such dry forest types have undergone significant shifts in forest structure, composition and disturbance regimes over the last century, stimulating the need for restoration (Hessburg et al 2005). Management practices include cattle grazing, and forestry; a series of forest thinnings with different specifications have been carried out in the last several years, with the most recent, in 2016, having been designed to enhance spatial heterogeneity for restoration purposes following recent ecological guidelines (Larson 
and Churchill, 2012). This treated area is scheduled to be prescribed burned in fall 2018. In the present paper we describe research data collected on a prescribed fire carried out in October 2017.

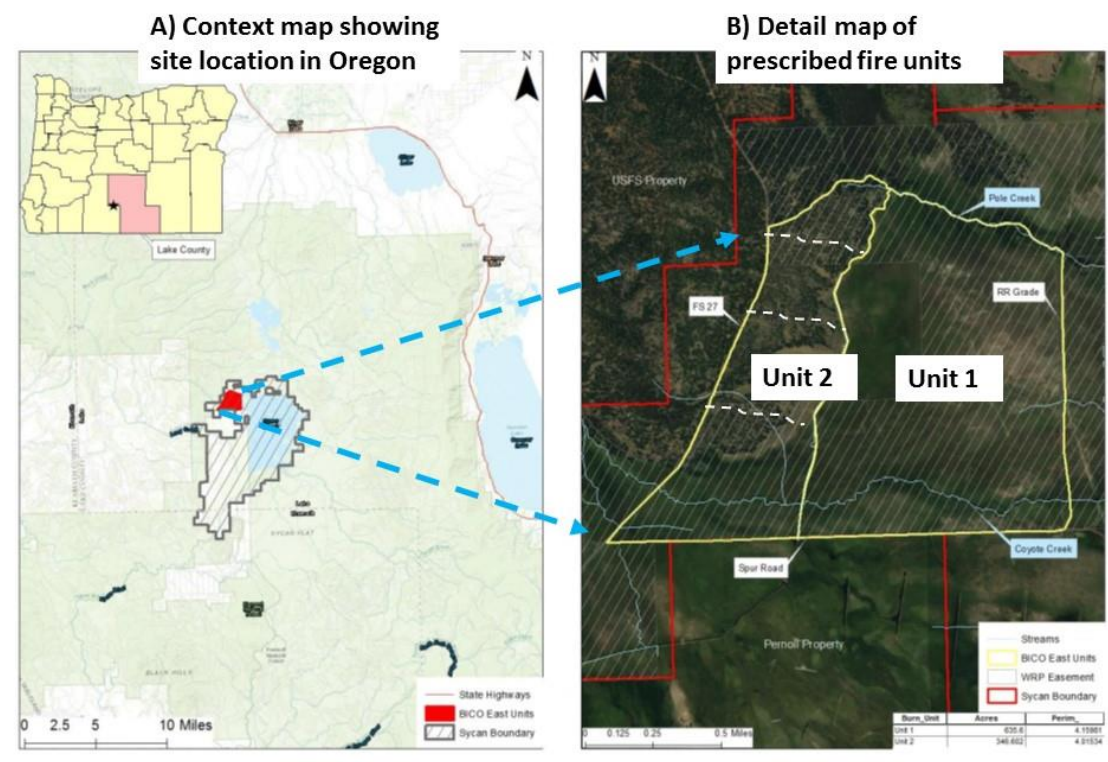

Figure 1 - Site location

\section{2017 Prescribed fire}

The 2017 prescribed fire was located in the northwestern portion of the Sycan Marsh Preserve, and totalled 398 ha, divided into a grass unit (Unit 1, 257.5 ha) and a forest unit (Unit 2, 140.5 ha) (Figure 1). Unit 1 had been previously prescribed burned in 2013, and about $80 \%$ of Unit 2 had been prescribed burned in 2006 following a conventional thinning operation. Management objectives in the grass area (Unit 1) were to reduce encroachment of lodgepole pine and juniper into the open prairie and increase native bunchgrass and forb densities, while management objectives in the forest area (Unit 2) focused on fuel reduction and maintenance of low density, resilient forest structure. Unit 1 was burned on October 11, 2017. Unit 2 was burned the following week, divided up into sub units burned in succession over a two day period (October 17 and 18). The northern portion of Unit 2 was not burned due to concerns of possible escape. In both units, ignition patterns were modified in the vicinity of focused data collection areas (described below) to permit free-burning fire conditions.

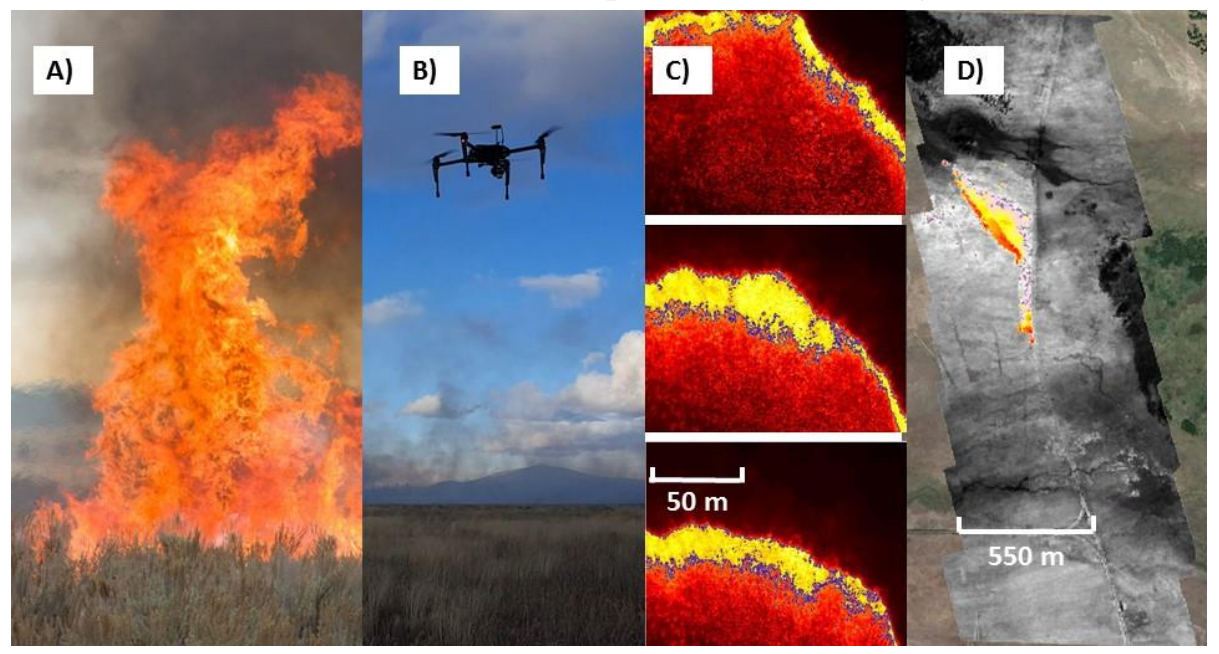

Figure 2 - Cross-platform fire behavior observations link A) surface fire behavior in sagebrush, B) drone-based thermal mapping, C) example drone plot fire progression, shown at intervals of $\sim 10$ s between selected frames, and D) airborne thermal imagery for a single flight line at a point in time. 


\section{Fire Science Research Data}

As wildland fire science continues to mature, the field is gaining new capabilities to embrace and understand complexity; rather than focusing entirely on steady state behavior and rate of spread, researchers can now explore interactions and gain insights into more fundamental physical quantities and their interactions (Yedinak et al 2018). Modeling plays a critical role in this expanding capability. While a growing body of evidence illustrates the performance of the physics-based models (e.g. Linn et al 2005b, Mell et al 2009, Pimont et al 2009, Hoffman et al 2016), model evaluation, through comparison against robust, integrated datasets is essential. Several complementary datasets were collected as part of this project, characterizing fuels, fire behavior, weather and emissions. Fuel mapping efforts, currently underway, will integrate surface and canopy fuels sampling, LiDAR and drone-based imagery. As the prescribed burn units are fairly large, fuel and fire behavior measurements centered on focused data collection areas called "drone plots" of $100 \mathrm{~m}$ x 100m, within which extensive field sampling, and drone-based fuel and fire mapping, took place. Drone-based fuel mapping was carried out with significant end- and side-lap image collection at high resolution, enabling highly detailed 3D fuels mapping through photogrammetric approaches. This data complements high quality airborne LiDAR data from 2010 and airborne imagery from 2016. A prototype 3D fuel modeling system, STANDFIRE (Parsons et al. 2018, Pimont et al 2016), will be used with this data to develop fuels inputs to the WFDS (Mell et al 2009) and FIRETEC (Linn et al 2005) physics-based fire models, providing a means for model evaluation against observed data. Fire behavior observations (Figure 2) within the drone plots included fire behavior packages (Butler et al 2004), oriented both horizontally and vertically (Unit 1 only), drone-based thermal nadir imagery (Figure 2 B and C) taken with a frequency of $\sim 1 \mathrm{hz}$, complemented by airborne thermal imagery capturing the larger burn unit with multiple images captured over the course of the burn (Figure $2 \mathrm{D}$ ). Wind data consisted of a large number of $3 \mathrm{~m}$ anemometer towers complemented by a SODAR collecting 3D wind data at $10 \mathrm{~m}$ intervals for several hundred meters of height. Finally, emissions data were collected using sensors on an aerostat (large ballon) and a vehicle. Data processing is ongoing at this time; upon completion, experimental outcomes and associated data will be published and made available to the larger fire science community.

\section{References}

Butler BW, Cohen J, Latham DJ, Schuette RD, Sopko P, Shannon KS, Jimenez D and Bradshaw LS (2004) Measurements of radiant emissive power and temperatures in crown fires. Canadian Journal of Forest Research, 34(8), 1577-1587.

Hessburg PF, Agee JA, Franklin JF (2005) Dry forests and wildland fires of the Inland Northwest USA: Contrasting the landscape ecology of the pre-settlement and modern eras. Forest Ecology and Management 211, 117-13.

Hoffman CM, Canfield J, Linn RR, Mell W, Sieg CH, Pimont F and Ziegler J (2016) Evaluating crown fire rate of spread predictions from physics-based models. Fire technology, 52(1), 221-237.

Larson AJ, Churchill D (2012) Tree spatial patterns in fire-frequent forests of western North America, including mechanisms of pattern formation and implications for designing fuel reduction and restoration treatments. Forest Ecology and Management 267, 74-92

Linn R, Winterkamp J, Colman JJ, Edminster C, Bailey JD (2005a) Modeling interactions between fire and atmosphere in discrete element fuel beds. International Journal of Wildland Fire 14, 37 48.

Linn RR and Cunningham P (2005b) Numerical simulations of grass fires using a coupled atmospherefire model: basic fire behavior and dependence on wind speed. Journal of Geophysical Research: Atmospheres, 110 (D13). 
Mell W, Maranghides A, McDermott R, Manzello SL (2009) Numerical simulation and experiments of burning douglas fir trees. Combustion and Flame 156, 2023-2041.

Parsons RA, Pimont F, Wells L, Linn RR, Cohn G, Jolly WM, de Coligny F, Rigolot E, Dupuy J-L, Mell W, and Linn RR (2018) Modeling thinning effects on fire with STANDFIRE. Annals of Forest Science 75(1), 1-11

Pimont F, Dupuy J-L, Linn RR, Dupont S (2011) Impacts of tree canopy structure on wind flows and fire propagation simulated with FIRETEC. Annals of Forest Science 68, 523-530. doi:10.1007/s13595011-0061-7

Pimont F, Parsons R, Rigolot E, de Coligny F, Dupuy J-L, Dreyfus P and Linn RR (2016) Modeling fuels and fire effects in 3D: Model description and applications. Environmental Modelling and Software 80, 225-244

Yedinak KM, Strand EK, Hiers JK, and Varner JM (2018) Embracing complexity to advance the science of wildland fire behavior. Fire 1, (2) 20 